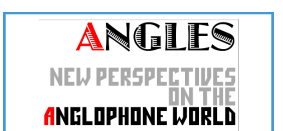

ANELOPHONE WORLD

\section{Angles}

New Perspectives on the Anglophone World

$13 \mid 2021$

The Torn Object

\title{
The Writer's Action Group (WAG) and the Fight for Public Lending Right (PLR)
}

Joseph Darlington

\section{(2) OpenEdition}

1 Journals

\section{Electronic version}

URL: https://journals.openedition.org/angles/3938

DOI: $10.4000 /$ angles.3938

ISSN: 2274-2042

\section{Publisher}

Société des Anglicistes de l'Enseignement Supérieur

Printed version

Date of publication: 15 December 2021

\section{Electronic reference}

Joseph Darlington, "The Writer's Action Group (WAG) and the Fight for Public Lending Right (PLR)",

Angles [Online], 13 | 2021, Online since 15 December 2021, connection on 29 December 2021. URL:

http://journals.openedition.org/angles/3938 ; DOI: https://doi.org/10.4000/angles.3938

This text was automatically generated on 29 December 2021.

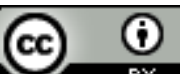

Angles est mise à disposition selon les termes de la Licence Creative Commons Attribution 4.0 International. 


\title{
The Writer's Action Group (WAG) and the Fight for Public Lending Right (PLR)
}

\author{
Joseph Darlington
}

\section{Introduction}

1 The Writer's Action Group (WAG) was a campaigning organisation founded and spearheaded by the experimental novelists Brigid Brophy and Maureen Duffy. Its principal aim was the institution of a Public Lending Right (PLR) system within the UK, a system by which authors received a small payment every time their books were borrowed from the public library. The group was established after Duffy and Brophy raised the issue of PLR with the UK's representative body for writers, the Society of Authors, only to find their approaches rebuffed. Set up in 1972, the Writer's Action Group built public and institutional support for Public Lending Right over two years of campaigning, culminating in the Public Lending Right Act being finally sworn into law in 1979.

2 During the short years of its existence, WAG's chief antagonists were the conservative establishment within the Society of Authors who at first rejected PLR entirely, before later proposing a diminished version in opposition to the WAG proposals. During the first phase of its existence, WAG was dominated by experimental writers. Brophy and Duffy were joined by Eva Figes, B.S. Johnson and Giles Gordon as the most prominent WAG voices in the press. By 1973, WAG metastasised into a national movement, with regional divisions established, and a range of alternative approaches to PLR emerging within these divisions. This phase culminated in an attempt to overthrow the Society of Authors' Annual General Meeting (AGM) in the summer of 1973. WAG motions were pushed onto the Society's agenda, all of them being defeated at the ballot, but only after a spectacular showdown. In the final phase of the WAG campaign, its biggest name, Ted Hughes, rallied behind the campaign, as did many within the emergent 
second wave of the feminist movement. When the PLR Act was finally passed, it was in the form that Brophy and Duffy had first envisioned back in 1972.

The concerted campaigning of Brophy and Duffy overcame resistance from the Society of Authors as well as challenges from within the movement itself over their ideas. In this article I hope to outline the history of WAG, some of its key players and their roles, the political struggles both inside and outside of the organisation, and some of what this meant for the future of writing in Great Britain, particularly experimental or otherwise minor literatures.

The majority of the research informing this article was drawn from the Writers' Action Group archive and reinforced by interviews with WAG participants alongside a range of secondary sources. It uses materials sourced from a wide range of archives including the British Library, Kings College London, the Manchester John Rylands, the Harry Ransom Centre in Austin, TX, and the Lilly Library, Indiana. Due to the size and scope of WAG's operations this article is by no means exhaustive in its coverage of the organisation, and instead seeks to tell the story of WAG through the actions of its key players and the development of their core message, charting the rise of WAG from a personal passion project through to a radical movement and finally into a mature campaigning body.

\section{Making the Case (1972)}

5 The origins of WAG can be found in a small circle of friends discussing politics at a gathering in Hampstead. The editor Victoria Bonham-Carter blamed the dual forces of wage stagnation and monetary inflation for the considerable reduction in writer's pay that had taken place over the past ten years. The writers Maureen Duffy and Brigid Brophy were acutely aware of this, having seen their own incomes fall despite a growth in sales over the stated period. A solution to this problem was initially proposed by Maureen Duffy, and was enthusiastically embraced by the five friends present: the adoption of a Public Lending Right (PLR).

6 Public Lending Right was, by 1972, a system already operating within a number of European countries. First introduced in Denmark in 1942, its most successful implementation was in Sweden in 1955. It was the Swedish system Duffy proposed to mimic. It allocated central government funds to writers in direct relation to the number of times their books were borrowed from public libraries (Brophy and Duffy 21/12/1972). Although the payment for a single lending was very small, the potential for each book to be borrowed numerous times, and for these borrowings to be multiplied across the entire nation, meant that these small incremental payments soon grew into a meaningful sum for the author. The Swedish government had adopted PLR as part of its developing welfare state project (Larsson et al. 2012). By contrast, Britain's post-war expansion of the state was reaching a critical point, and there was a very clear sense that the economy would soon enter recession. Nevertheless, the friends argued, PLR was still a reasonable measure for which a reasonable case could be made. It could even be seen as a means of protecting British writers at a time when economic recession threatened their capacity to earn a living from their work.

7 After conducting what they felt was sufficient research to understand and make a case for PLR's adoption in the UK, they decided to approach the Society of Authors. Brophy was chosen to make their case, being an accomplished public speaker, well-known for 
her appearances on radio and television shows, as well as already being a seasoned campaigner for animal rights. They met with a delegation of the Society on $12^{\text {th }}$ July 1972, making their case directly to members of the Committee of Management in the hope of winning over their support (Bonham-Carter 12/7/1972). The Society of Authors was unaccustomed, however, to the kinds of political pressure that Brophy was entreating them to exert. Despite its claim to be the representative body for writers within the UK, the Society's everyday activities were limited to the managing of its premises, which took the form of a social club of sorts for old and retired writers, and the production of documents advising on typical rates of pay, copyright agreements, and contracts. Functionally, the Society operated as an advisory body offering support to individual writers. Politically, it understood writers to be sole traders, individually responsible for their own relationships with publishers, literary agents and other employers.

8 The approach outlined by Brophy, by contrast, implicated her and her friends in an understanding of writers as a class defined by their shared trade. The advocacy they sought from the Society was more reminiscent of a trade union or a pressure group than an advisory body. Their differences, even at this initial point, can be understood as primarily philosophical, with the issue of PLR itself a secondary concern. Nevertheless, PLR would be the battleground over which these political differences would be contested. Already aware of the threat posed by Brophy's group, the Society attempted to defer them by placing Brophy in charge of an advisory subcommittee tasked with assessing the viability of PLR. The subcommittee also came with a caveat: that Brophy agree to withdraw a motion she had submitted to the Society's 1972 AGM to discuss her group's proposals for PLR. Agreeing that a subcommittee was the right way forward, Brophy withdrew her motion and was allocated Chair (Bonham-Carter 27/7/1972). To Brophy's frustration, however, the subcommittee soon collapsed into farce. The Society elected certain members to it who had no intention of ever turning up, and regularly scheduled other important meetings alongside it, meaning that the subcommittee's meetings were often called off, having failed to reach quorum. Brophy knew that she was being fobbed off and resigned her place as Chair to pursue another plan.

9 Angry at the Society of Authors for their conservative stance, and humiliated by their pettifogging tactics, Brophy and Duffy founded the Writers' Action Group (WAG) in September 1972, several weeks after Brophy had first approached the Society of Authors with the PLR proposal. The stated aim of WAG was the adoption of PLR into British law, and their unspoken adversaries in this were the grandees of the Society of Authors who, despite their reticence to engage with members directly, still held the claim to be the national representative body for writers. Until the Society were on their side, it was unlikely that Parliament would accede to WAG's demands.

The first step for the newly inaugurated WAG was to begin spreading their message and recruiting members. Maureen Duffy and Brigid Brophy stepped forward as the leaders of the group at this time, with the rest of the founder members taking a back seat. As with when Brophy was chosen to approach the Society of Authors, she took a publicfacing role on behalf of WAG. Between the establishment of WAG in September and the end of the year, she wrote seventeen different articles on the issue of Public Lending Right and had them published in journals as diverse as New Scientist, the Evening Standard and The Observer (Duffy 1972). Left-wing periodicals, New Statesman and the 
Guardian, were particularly receptive to the message, publishing three and four articles on PLR respectively through the autumn of 1972. The Bookseller, meanwhile, published five. Being the trade magazine of the publishing industry, the issue of PLR was of core concern to them and with each article they ran there followed an extensive and prolonged discussion in their letters pages (Duffy December 1972). These letters were not only aimed at the Bookseller, but at WAG too. Correspondence mounted in the WAG PO box, with each one of Brophy's articles bringing a new wave of complaints, queries, and messages of support.

Where Brigid Brophy adopted a public facing role for WAG, Maureen Duffy became the organisation's de facto secretary. She handled membership lists and donations. Early members included Doris Lessing, whose support was limited only by the large number of other campaigns and causes to which she was already pledged, and Anthony Burgess, who heard Brophy talking about PLR on the BBC World Service and was convinced enough to join the cause despite the two writers' personal rivalry (Duffy 14/7/1972). The number of letters applying for membership and pledging support were far outweighed by those criticising the WAG plan, or asking for clarification. Duffy responded to many of these personally at first before coming to realise that solid policy statements were necessary both to maintain a consistent line and to make the processing of mass correspondence more efficient. A clear line was needed in order to dissuade the many misconceptions and, at times, outright slurs being directed at the campaign. The Times, in particular, persistently cast WAG in an unsavoury light, often referring to them as "the extremist Writer's Action Group" ("Public Lending Right" 1973). Duffy was constantly penning letters to their editor complaining of misrepresentation, up to and including a "Times Diary" piece in January 1973 claiming that the government, prompted by WAG, were planning on charging libraries an extra $£ 1$ per book in a special PLR tax (Brophy and Duffy 2/2/1973). Such a proposal was at total variance with WAG's aims, they assured the editor, and WAG did not yet have the ear of government to make itself heard anyway.

The arduous work of writing these response letters shaped Duffy into WAG's resident policy expert. Where Brophy was a master of erudition, producing articles dense with rhetorical flourishes, Duffy instead amassed the weight of statistical and legal knowledge required to understand the complex issue of PLR from a technical standpoint. Her research uncovered the fact that, despite both sales and borrowings increasing every year since the end of the war, writer's earnings had fallen. In fact, due to the excessively high inflation rate of $63.4 \%$ between 1966 and 1974, the average writer's earnings had not only frozen but had declined to only a quarter of what they had been in 1965 in real terms (Williams qtd in Coe 2004: 348). Library borrowing had expanded massively during these years, with an average of thirteen books a year being borrowed per person, adult or child, free from the library (Brophy and Duffy $9 / 3 / 1973$ ). Fiction accounted for $73 \%$ of these borrowings (Duffy 2/10/1973). And yet, despite the huge amount of fiction being read in Britain, the publishing prospects for fiction books were almost nothing compared to non-fiction and reference books. Duffy herself was often pressured by her publishers to drop experimental novel writing in favour of literary criticism or polemical works (Seddon 2014: 140). The reason for this was that a single fiction sale to a library might result in ten, twenty, or a hundred loans, all for the price of a single paperback. Non-fiction books, meanwhile, drew a smaller but more specialist market more willing to purchase the books themselves, and to do so at the higher price asked for hardbacks. Compared to France, where less fiction was read but 
far more was purchased, and it could be argued that Britain's public library system was turning British authors into the one of the most read and yet least rewarded literary classes in Europe.

With the statistical evidence for Britain's writing crisis at hand, it then fell to WAG to construct a viable plan for their proposed solution: PLR. Again, Duffy was the one primarily conducting the research. As well as becoming fluent in British governmental procedure, Duffy researched the Swedish system and the way it was financed, hoping to simply copy the Swedish model. However, where the Swedish library system was centrally funded, Britain's was paid for by local councils and was therefore tied to local council tax rates. Where PLR could simply be added to the library budget in Sweden, adding to government borrowing on a macro level where individual voters would not notice it, the British system would not allow such a relatively simple process of addition. Instead, a British PLR would either have to be 1) drawn from existing library budgets, 2) added to council tax bills as an additional expense, 3) charged directly to the borrower, or else, 4) handled by central government through the foundation of an entirely new PLR body. WAG were adamantly in favour of the latter, but knew that instituting this policy would mean a far larger undertaking for government than had been the case in Sweden (Duffy 2/10/1973).

The final shape of the WAG proposals, agreed in October 1973 after a solid year of campaigning, was to be a mix of the Swedish system and other comparable systems drawn from across the globe. As to whether an author should be paid per book sold or per loan, WAG mimicked the "residuals" system used in the music industry in calling for payment per loan. Unlike residuals, however, the money wouldn't go to publishers (the literary equivalent to the record companies), but directly from government to the writers themselves. Measuring the number of loans would be made simpler by adopting a system similar to Neilsen ratings, where select participating libraries would be canvassed and the results for each would be taken as representative of all public libraries in their area. This information would be sent to a central government body responsible for the calculation of PLR payments and their disbursement to writers (Duffy 2/10/1973). In a piece of remarkable forward-thinking, Duffy suggested that the government could automate a large percentage of these calculations through new computer technology. She had even selected the best computers for the job and calculated that roughly 200 machines would be suitable for the required task (Duffy [1973a]). Whether it was Duffy's interest in science fiction writing that led her to this conclusion is unknown. Either way, once WAG's proposals were finalised in early 1973, it became eminently clear that not only was PLR politically justifiable, but it was also technically and financially possible. The work would now be to convince the public, the government and, more resistant than any, the Society of Authors, of this fact.

\section{WAG Expands and Radicalises (1973)}

By 1973 it was clear that WAG was more than just Brigid Brophy and Maureen Duffy's pet project. The furore in the letters pages placed PLR in the public eye with increasing regularity, and the solidification of WAG's idea into concrete proposals allowed Duffy to respond to the tidal wave of correspondence with an ever-growing assurance that their policies were both functional and valuable. It was at this point that other famous authors began gravitating towards the organisation. Among these were the humourist 
Basil Boothroyd and Iris Murdoch, whose James Tait Black Memorial Prize win later in the year would draw yet more attention for the cause. A large experimentalist contingent also joined WAG, no doubt attracted by the experimentalist credentials of its two leading figures. B.S. Johnson joined in March of 1973 alongside Eva Figes. Alan and Carol Burns pledged support soon after and, through Johnson, the editorial director of Gollancz, Giles Gordon, joined as well ("Lending Rights and Wrongs" 1972).

Johnson was well-known as an abrasive figure, even among those he considered his friends. Money was a point of constant contention with him, as was the notion of a literary establishment who stood against all things experimental and innovative. These were the writers that Johnson disparaged as, in the great "relay race" of literature, "the baton of innovation passing from one generation to another", they had either "dropped the baton, stood still, turned back, or not even realised there was a race" (Johnson 1973: 30). The attraction of WAG for Johnson was obvious: here was a chance to rail against the establishment, in the form of the Society of Authors, and potentially gain a new revenue stream in the process. Johnson's politics regarding money could be wildly unpredictable. Only a few years earlier, for example, he had written to the Times Literary Supplement after they had published an attack on Arts Council bursaried writers and argued that English lecturers ought to be measured against an "efficiency bar". Unsuccessful candidates should be fired, he argued, so that "public money [would not be] spent on bad ones" (Johnson 1969). The letter was never published. He could also be wildly successful in his demands, however, such as in his dealings with Secker and Warburg. According to Rayner Heppenstall, Johnson received:

A $£ 1200$ advance out of Fred Warburg on each of two novels to be written in three years. He said that he needed, during those three years, the equivalent of, say, Fred's secretary's salary, which was $£ 800$ a year. This appealed to Fred's sense of fair play. So it should, but it was a great deal more than a new novelist had ever had before in the United Kingdom (Heppenstall 1986: 108)

17 Johnson's tendency to measure self-worth in terms of money made him a militant campaigner for pay, both his own and that of writers more generally. It could also make him obnoxious, impatient, and combative. For a campaigning organisation, this could prove to be a benefit.

Giles Gordon had been drinking buddies with B.S. Johnson for years and had only grown closer to Johnson after becoming the editorial director of one of the country's biggest publishers, Gollancz Press. Johnson had encouraged Gordon's own writing aspirations, leading eventually to the publication of a series of experimental books including Pictures from an Exhibition (1970) and Umbrella Man (1971). Johnson had already negotiated Gordon into a powerful position within the Arts Council, allowing him to favour experimentalists when it came to awarding bursaries and prizes, and by bringing Gordon into WAG too, the organisation suddenly gained access to powerful establishment figures. Immediately following Gordon's initiation into WAG in March 1973, he organised a meeting with MP William Harding. Harding was immediately won over to the PLR cause and even signed a joint letter alongside Duffy, Brophy, Johnson, and Gordon that demanded The Times retract a number of inaccurate and misleading statements they had made about WAG and their PLR proposals (Harding et al. 1973). Without the backing of the Society of Authors, however, Harding said that his party would never be able to fully adopt PLR at policy level; it was still too contentious. Undiminished in his enthusiasm, Gordon moved from the Commons to the Lords, having dinner with Lord Grossman in October 1973 and pitching him an idea for an 
International Centre for Writers that would, among other things, unify PLR internationally and allow writers to claim money for international loans (Gordon 29/10/1973). After much initial enthusiasm, nothing came of this plan either.

Within WAG itself, positions were hardening. The proposals solidified in early 1973 may have served as the official version of PLR supported by WAG, but new ideas and proposals were emerging all the time. At a time of increasing political turbulence, WAG, like many other organisations, was under pressure to radicalise. Giles Gordon, despite his authoritative position in the world of publishing, was also the most outspoken member in favour of transforming WAG into a trade union. Johnson was another vocal supporter of these plans, and even suggested taking over the Society of Authors and turning it into a union instead (Wollaston 4/6/1973). Nicholas Wollaston, a travel writer and member of the Society, took this cause to heart and proceeded to campaign for it within the Society itself. Maureen Duffy, meanwhile, was planning a trip to Moscow in the hope that she might learn something from Soviet society (a desire she would formalise in the title of her 1973 novel I Want to Go to Moscow) (Gordon [1973]). All of this was total anathema to the Society of Authors and seemed to be confirming the fears of the most conservative voices on their governing committees. Once a place where an old author might come for a cup of tea and a chat about books, the Society was now on the verge of revolution ("Lending Rights and Wrongs" 1972).

The further the word spread, the more writers joined, and the more diverse became the range of voices within the organisation. By June 1973, WAG could claim 235 writer members and 40 associated members (these included supporters, literary agents, politicians, and even some publishers and librarians) (Brophy 20/6/1973). The movement was metastasising, with each new member being encouraged to spread the word and bring in more members. Soon the decision was reached to decentralise the movement, with regional divisions being formed, each with their own Chairs and a degree of autonomy. Maureen Duffy remained as national secretary, with Brigid Brophy as their figurehead, but Duffy's role now became one of coordination between divisions. The role was not a simple one, especially as new divisions tended to form their own cultures and pursued the shared goal of PLR in very different ways. The Yorkshire Division, for example, were staunch conservatives, and following the lead of their charismatic Chair Arthur Wise, primarily saw PLR as a means of redistributing author's pay away from the London-centric publishing scene. Too many good Northern writers were forced to travel South to earn a living, Wise argued, stripping the North of its culture as a result (Wise 4/7/1973). The East Anglian Division, by contrast, was the political opposite, being dominated by Cambridge Marxists. Jack Lindsay, David Holbrook, and Raymond Williams were all active members, and they made no excuses for seeing WAG as just another step on the road to socialism (East Anglian Division 16/11/1973). "My advice to the Writer's Action Group," Lindsay wrote in a letter to The Times, "is to keep on rocking the boat in the hope that the right persons will fall overboard" (Lindsay 18/8/1973). The Times, keen to paint WAG as an "extremist" group of revolutionaries, gave Lindsay's message prominent placement on their letters pages. Most Divisions weren't as politically polarised, however. The South West Division was dominated by crime writers whose main concern was the pragmatics of PLR payments. Despite crime being the most popular genre among library borrowers, a WAG poll revealed that around half of all crime writers lived on less than $£ 1,500$ a year, and if it wasn't for international sales then the great British detective novel would soon disappear ("Crime Writing Does Not Pay, Say Authors" 1973). By October, there was 
even an American Division. The Americans realised that spending public money on the arts would not prove popular in the United States and so pushed for copyright reform instead, creating a private sector version of PLR marketed as "residuals for authors" (Ross 11/10/1973). Overall, the Division system provided WAG with a much-increased reach, while also threatening to obfuscate their central message through a diverse, and often contradictory, range of voices.

Figure 1: Campaigning by the Writer's Action Group (c. 1973)

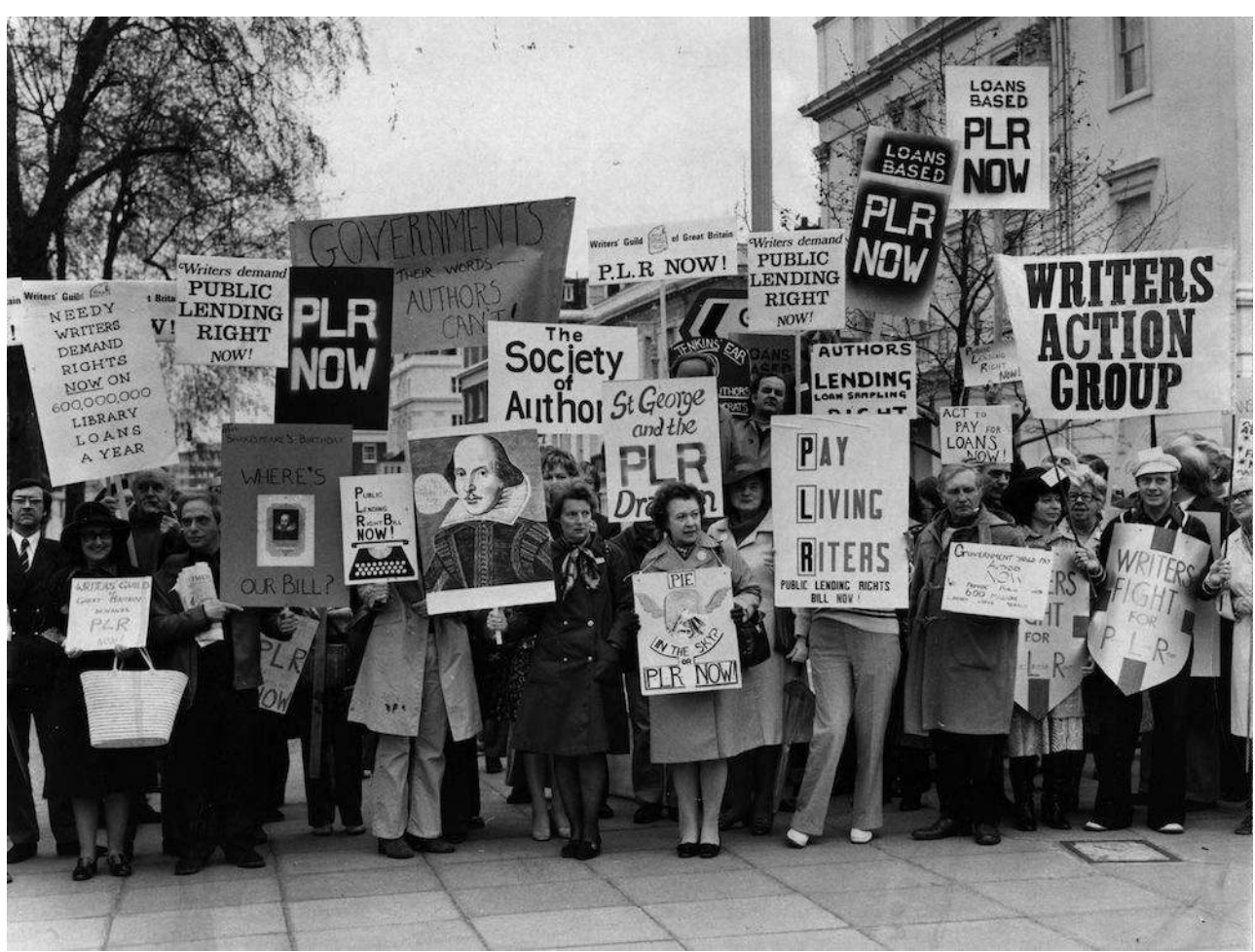

Source: https://tribunemag.co.uk/2021/03/the-writers-action-group-is-a-model-for-todays-fight-forthe-arts

21 With WAG's numbers growing and the momentum firmly behind them, the stage was set for a showdown. The catalyst was provided by the Society of Authors themselves after an unfortunate political miscalculation. Realising that WAG were now a power to be contended with, the Society hoped to ease tensions by inviting WAG to contribute an article to the Society newsletter. It was hoped that both the WAG position and the Society position on PLR could be placed next to each other, and their readers would be able to decide for themselves which position they supported. WAG had other plans. Assigning radical writer Gordon Williams the task of presenting their case, the resulting article began with a numerical breakdown of exactly how much writer's pay had fallen in the past decade - earning only "a third to a quarter" of what they had in 1966 - before moving on to attack the Society itself in intensely critical terms for its culpability in this dramatic loss of earnings (Williams qtd in Coe 2004: 348). The article caused an uproar. Maureen Duffy, chairing a meeting of the London Division, WAG's biggest group, barely managed to contain a group of writers who threatened to march to the nearest library and deface books in response to Williams' article (Yorke 20/11/1973). Instead, a plan was made to disrupt the Society of Authors' Annual General Meeting. WAG had been promoting Society memberships to its members with 
the idea that some time down the line they could stage a coup from within, and it seemed as if that time had come. With the aid of Nicholas Wollaston, WAG's man on the inside, Maureen Duffy managed to get the issue of PLR onto the AGM ballot. Brigid Brophy proposed that a representative group of four WAG members be elected to the Society steering committee, and Johnson and Gordon even managed to bring the issue of unionisation on to the agenda (Duffy 3/7/1973).

The preparation for the coup began in earnest. Members went on a recruiting spree. Johnson encouraged Alan and Carol Burns to join the Society, who in turn brought John Calder and many of his group of experimentalists, all in the name of "overthrowing and trampling on the old guard" (Burns 1/7/1973). A memo went out to all members of WAG reminding them to renew their Society memberships and inviting them to the AGM. A similar message was even printed in The Times where, despite an editorial line generally opposed to WAG, the PLR issue was slowly gaining traction. The advert drew attention to the Society of Authors' AGM and asked that anyone interested in attending read up on WAG's PLR proposals beforehand ("Letters" 1973).

The result was, to WAG's great disappointment, a series of defeats across the board. WAG's success in advertising the AGM to its members had also served to mobilise the Society of Authors establishment. Where many of the old guard had been complacent before, the 1973 AGM revealed to them the scale of the threat posed by WAG and the potential challenge to the old ways that it represented. During the AGM itself, the room divided into two sides, with raucous shouting and jeering taking place prior to order being called. B.S. Johnson threw paper darts across the room at the "Society Tories", as he called them, crying "shame!" whenever someone spoke against WAG (Figes 1985). The meeting began with the usual business of the Society AGM, including membership numbers, an overview of annual accounts, and a series of minor issues regarding the Society cafeteria. Once this business was concluded, the ballots began. Duffy's ballot on PLR, asking the society to back WAG's proposals, was voted down. It was a close vote, $42 \%$ in favour to only $54 \%$ against, but it spelled the end of WAG's attempt at entryism (Duffy [1973b]). Predictably, the ballot on unionisation was voted down, and no vote was even held for Brophy's proposal as it was ruled to go against Society protocol. A final cathartic moment was provided by a ballot added to the agenda in the "any other business" section, however. Proposed by B.S. Johnson, the ballot called for the resignation of the entire Society of Authors Committee of Management for their atrocious handling of writer's pay and the PLR issue. The ballot was, of course, defeated, but it gave a last-minute boost to the jeering WAG members who proceeded to leave the hall in a state of jocular defiance.

In the aftermath of the attempted insurrection at the AGM, the Society of Authors contacted Maureen Duffy, Brigid Brophy, and B.S. Johnson privately to ask if they would agree to reinstate the PLR sub-committee opened a year ago (Holroyd 16/11/1973). Brophy and Duffy politely accepted the offer, recognising it for the concession that it was. Johnson, on the other hand, wanted nothing more to do with the Society of Authors. He had instead become enamoured of the terrorist group The Angry Brigade, attending their trial with friend and co-conspirator Alan Burns, research that would eventually surface as Christie Malry's Own Double-Entry (1973) (Darlington 2014: 89). Maureen Duffy would later recall Johnson's activism in WAG as being primarily conflict-oriented. He enjoyed the swagger and bluster involved in attacking the Society, an organisation he saw as the embodiment of his mortal enemies: the literary 
establishment. But when it came to the quiet work of building membership, gathering information, writing functional policy, and making concessions, Johnson found it all rather insipid, if not emasculating. "I think he found it quite difficult," Duffy said, "that it was basically being run by a coven of women" (Seddon 2014: 140). The task of WAG post-AGM would be to rebuild relations with the Society and gather the momentum necessary to bring their proposals to government. Reconciliation was not on Johnson's mind at this time, nor was it for many of the most radical members.

Giles Gordon also left WAG shortly after the AGM. In a long letter to Brophy and Duffy he argued that, as the Society would never be successfully transformed into his longedfor "union for writers", he would instead aim to take up membership of their neighbouring union Sogat. Sogat was the printer's union and so, in Gordon's mind, this represented a natural alignment of the writers of books with those who made them (Gordon 6/8/1973). Maureen Duffy, in an even longer letter back to Gordon, pointed out that, as PLR was of no benefit to printers, it was unlikely that Sogat would be any more receptive to WAG's proposals than the Society would be. In practice, there were also a lot more printers than there were authors. Even if every member of WAG were to join Sogat overnight, she calculated, then there would not be enough authors to elect a single member onto Sogat's 32-member steering committee. At best they could claim "one-tenth of one man" (Duffy 8/8/1973). For WAG, Duffy argued, the route to PLR went directly through the Society of Authors. It was the Society or nothing, and for Johnson and Gordon this meant choosing nothing. A small contingent of hotheads left with them, although on the whole the membership of WAG continued to grow, and many of the new members were far more patient than were these experimentalists. Heading into 1974, the majority of WAG membership in fact became supporters at a distance. The membership lists swelled as attendance at meetings dropped to a small hardcore of committed writers. The organisation was evolving from a publicity campaign into a professional pressure group.

\section{Approaching Government (1974)}

By 1974 WAG had over five hundred members and ninety associate members ("Editorial" 1974). Even after the Society of Authors' AGM, when a number of core members turned in their cards, growth remained consistent. The divisions system assured that growth was spread across the country, not just focused on the London literary scene, and as a result the "silent majority" that the Society often believed itself to be representing were no longer quite so silent. With letters flowing in from every corner of the nation in support of PLR, the Society decided to seek a compromise solution. Michael Holroyd, a prominent voice within the Society and Chair of the 1973 AGM, began attending Brigid Brophy's subcommittee, bringing with him an alternative PLR proposal that he believed both WAG and the Society grandees could get behind. It was on these more precise contractual terms that the next stage of the PLR campaign would be fought.

The fundamental differences between the Society's proposal and the terms outlined in WAG's policy document of 1973 were to do with the inclusion of publishers. WAG included some publishers within its associate membership but, as a whole, the organisation was primarily concerned with writer's pay. As much of the blame for the severe drop in pay could be laid at the door of the publishers (who were themselves 
earning far more than they had in the mid-1960s), the typical WAG arguments tended to alienate those in the wider publishing industry. This drove many publishers to support the Society side of the debate as a knee-jerk reaction. In return for publisher's support and goodwill, the Society proposals were inclusive of publishers at every level. Contributions to authors would be mediated through a parallel publisherreimbursement system, with the central government funds going both to author and publisher upon the loan of a library book. According to WAG's calculations, this would result in a split of $75 \%$ to the author and $25 \%$ to the publisher on every borrowing (Duffy 10/5/1974). The Society believed this to be an adequate calculation, assuring that publishing companies received a return on their investments while authors too were reimbursed. WAG members were absolutely against it. The proposal "can hardly be regarded as adherence to the principle of providing just compensation to authors," Duffy wrote (Duffy 10/5/1974). The entire discourse around PLR had been framed by authors' pay and authors' rights, and so WAG were rightfully sceptical of a last-minute push by the Society to be publisher-inclusive. The differences here were important. On a conceptual level, the WAG proposals represented an extension of the Arts Council bursaries system: writers were rewarded for their work and for the added value that their cultural contributions made to the nation. The Society proposals, by contrast, transformed the author-centric reward system into something closer to a national subsidy for the publishing industry. Giving government money to publishers would be a clear shift away from the intention of rewarding writers directly. It may also have made PLR more difficult to pass in Parliament, as Conservatives who were otherwise keen on funding the arts may have baulked at channelling public money directly into the hands of private businesses.

As the knotty issues of precise PLR wording were being debated in Brophy's subcommittee, the wider WAG organisation slowly moved its attention away from the Society of Authors and towards the wider public and Parliament. Some MPs, like William Harding, were already sold on PLR, but there were many who would prefer a groundswell of public support to emerge before they made any direct commitment. In pursuit of a more effective lobbying model, WAG supplemented its divisions system with a further set of committees. The committees were modelled on Arts Council funding committees, being comprised of leading practitioners in specific mediums, holding debates that were particular to there area. Committees included Drama, Magazines, Poetry and Books. Eva Figes was elected as the Chair of the most powerful committee, the Books Committee ("Minutes" 17/11/1974). Here, the methods of campaigning specifically relating to books and authors would be debated, and routes into the national debate were proposed. Brophy's tried and tested method of article writing was always popular, but so were events and readings. The literary critic Cyril Connelly coordinated a massive book sale, ostensibly to raise funds for WAG but also an opportunity for supportive news coverage. WAG writers provided manuscripts, signed copies of their works and other special memorabilia for an auction and raffle (Lissauer 25/2/1974). Eva Figes herself, borrowing an idea from Calder's "Writers Reading" events, went on a public reading tour alongside poets Fleur Adcock and Ted Hughes. Hughes, already a literary heavyweight, was not yet a full WAG member but agreed to join the readings after the impassioned pleading of Figes and Brophy. As predicted, his readings drew attention from the national papers: "he is incredible", Ken Cox wrote, "blasting poems with a huge voice which can sink to a whisper" (Cox 1974). Ted Hughes 
would become a name nationally associated with WAG through these readings, despite his membership only being confirmed later on.

While Ted Hughes drew the attention of national print media, Eva Figes herself was acting as a draw, particularly among the feminist presses emerging from the countercultural underground. Figes' 1970 political book, Patriarchal Attitudes, sat alongside Kate Millet's Sexual Politics and Germaine Greer's The Female Eunuch as one of the foundational texts of a newly emergent feminist wave (Fountain 1988: 107). She was a regular commentator for the Guardian and Observer on women's issues, wrote on culture for feminist periodical Spare Rib, and often ventured outside of the typical feminist-inclined publications to write articles for Good Housekeeping, The Spectator and the Britannica Book of the Year ("Articles Box"). Figes' contributions to the growing network of writers and publications within the wider feminist movement made her a respected figure despite the fact that, being a single mother caring for two children, she had little time for political meetings or giving speeches beyond those for WAG (Thane 1991: 204). It was through her contribution to the women's liberation journal West One, "a journal published every Friday and distributed to 100,000 working women in London", that the journal itself committed to supporting the PLR cause. It was swiftly followed by Spare Rib and a succession of smaller feminist presses including the former Communist Party magazine Red Rag (Dulch 16/2/1974). For many feminists, PLR was just one of a whole raft of legislative changes they sought that would use state funding to provide support for women. For writers like Figes, PLR could assure some lasting income from her books so that she could support her children in the long term.

For Ted Hughes, the PLR issue was far more straightforward. Being an established writer, PLR would supplement his income considerably, albeit he was not in a similar position to Figes or Duffy as such supplementary income would not make a qualitative difference to his life. It is for this reason that Hughes joined WAG late in its campaigning, and perhaps also why his late arrival was accompanied by an overcompensatory zeal. Having already brought considerable public attention to WAG through his readings, Hughes hoped to build on this success through a massive national campaign. His proposed medium was drama, and particularly children's plays. Writing to Maureen Duffy and Brigid Brophy in 1974, Hughes suggested " 25 plays - big number - because that would make it a mine big enough for every desperate school drama producer to find something in, and it would make it an essential collection for the performing companies" (Hughes [1974]). These plays, contributed by WAG members, would span across a wide range of genres, "miracle-play, portable-play, dream-play, medieval possibilities of the form", and would also take into account "seasonal or ritual religious subjects", enabling them to be performed as part of festivals and fetes (Hughes [1974]). At any one time, Hughes estimated, around " 5 or 6 of them would be being done", with travelling performers supplementing the school groups and local theatre organisations so that these " 20 minute plays for children" could be performed "in every corner of the country" (Hughes [1974]). To facilitate this national dramatic revolution, Hughes also proposed the establishment of a "publishing house - a sort of writer's cooperative - to publish the collection". This "might develop as it has in Hungary and Sweden," into a movement of national importance in itself, but even if it didn't then "at least it would be feasible for this one collection" (Hughes [1974]). It goes without saying that Hughes' perception of feasibility was somewhat skewed. WAG's meagre funds could barely stretch to placing small adverts in the Times, let alone establishing a new publishing house and writer's cooperative. The energy and passion 
of its membership were not in question, but their efforts were, by mid-1974, being exerted almost entirely on subcommittees, correspondence and lobbying, leaving little time for writing 25 plays and touring them. Whether a relatively minor legal reform was suitable subject matter for a collected five hundred minutes, or 8.5 hours of theatre, is also questionable. Nevertheless, from an initial reticence, it was at least clear that Ted Hughes was now firmly on board with the WAG proposals and was willing to contribute his time, even if his ideas about how to contribute it were somewhat naïve.

With national support for PLR growing to a critical mass and a number of major names tied to their cause, WAG decided that the time was right to push for another dramatic lobbying effort. Rather than move against the Society which was by now ready to concede the publisher's share of PLR and was only quibbling over minor details of wording, it was decided that the group should undertake a mass lobby of MPs at Parliament. With this in mind, Duffy and Brophy wrote a press release inviting members of the press to join them, as fellow writers, in marching on Parliament and convincing the politicians that the time was finally at hand for the enactment of Public Lending Right (Brophy and Duffy 31/7/1974). Dozens of writers moved on Parliament and, to their surprise, found that instead of the resistance they were expecting, MPs from both major parties were very much behind WAG's PLR proposals. Unlike the Society of Authors, the House of Parliament was open and receptive to outsiders as long as, like WAG, they had built support gradually over a number of years and come through all the right channels in order to reach them. By the time of the mass lobby in 1974, the Writer's Action Group had effectively graduated from a "radical" splinter group into a recognised and respected national movement. All that was left now was for a legal team to undertake the long and protracted task of writing up a Bill suitable for the House, at which point a large number of sitting MPs who had already pledged support for PLR would encourage their party colleagues to do so too. The process, from here, was out of WAG's hands. They had, in two short years, achieved their goals and initiated change.

\section{Conclusion}

The Public Lending Right Act was passed in 1979 and has constituted the basis for all subsequent British PLR systems. The 1979 version follows the WAG proposals of 1973 closely, with subsequent revisions including yet more of WAG's suggestions such as computerisation and a representative sampling of library data. In 1993 PLR made its way into EU law with all member states expected to adopt their own versions. These were subsequently replaced by a centralised EU system of legislation in 2002 which is still used in all member states across Europe. Britain, in leaving the EU, has returned to a similar wording to that used in 1979, with the 2017 Digital Economy Act expanding PLR to include e-lending, the first reimbursements for which were paid on $1^{\text {st }}$ July 2018. Both the EU law and the subsequent British law are described on the Society of Authors website as "a great victory for SoA members" ("Public Lending Right" 2019). Data on library borrowing is collected from sample libraries within the British public library service and processed by an independent Public Lending Right Service, as Maureen Duffy initially proposed (although whether they use any more or less than her estimated 200 computers is unknown) ("Public Lending Right: How it Applies" 2019). The PLR Service - an independent body, as Duffy proposed - falls under the operations 
of the Department for Culture, Media and Sport, with registration for the PLR scheme being operated through the British Library ("PLR: Serving Authors Since 1979" 2019). The current reimbursement rate for a single library borrowing is $8.5 p$ (The Society of Authors 2019).

The campaign for Public Lending Right might not be the most glamorous aspect of the British experimental writing scene of the 1960s, but in terms of lasting impact it could be considered one of their most important contributions to British culture. Thanks to the efforts of Maureen Duffy and Brigid Brophy, and the dozens of writers and intellectuals who took up their cause, millions of pounds have now been redistributed from British central government funds to British authors. That the movement succeeded also confirmed that it was the quiet persistence of Duffy and Brophy that proved WAG's most valuable asset, and not the belligerent approach of Gordon and Johnson in 1973, or the extravagant performances of Ted Hughes in 1974. As a success, it was a quiet victory, both in terms of WAG's campaigning methods and the final effect of PLR, but its continuous effect within our modern world it is an important one, and well worth considering as part of the lasting legacy of 1960s British writers.

\section{BIBLIOGRAPHY}

Articles Box, Eva Figes Archive [uncatalogued]. Held in British Library.

Bonham-Carter, Victoria. Letter to Brigid Brophy and Michael Lang, $12^{\text {th }}$ July 1972. Held in King's College Archive.

Bonham-Carter, Victoria. Memo to the Society of Author's Secretariat, $27^{\text {th }}$ July 1972 . Held in King's College Archive.

Brophy, Brigid. Letter to John Wingate, $20^{\text {th }}$ June 1973. Held in King's College Archive.

Brophy, Brigid and Maureen Duffy. “Fighting On”. Evening Standard, 21 ${ }^{\text {st }}$ December 1972.

Brophy, Brigid and Maureen Duffy. Letter to the Editor at the Daily Mail, $9^{\text {th }}$ March 1973 . Held in King's College Archive.

Brophy, Brigid and Maureen Duffy. Letter to the editor of The Times, $2^{\text {nd }}$ February 1973. Held in King's College Archive.

Brophy, Brigid and Maureen Duffy. Press Invitation, $31^{\text {st }}$ July 1974 . Held in King's College Archive. Burns, Alan. Letter to B.S. Johnson, $1^{\text {st }}$ July 1973. Held in British Library.

Coe, Jonathan. Like a Fiery Elephant. London: Picador, 2004. P. 348.

Cox, Ken. "Frisbees and Lunch in a Train". Quoted in West One, $16^{\text {th }}$ February 1974.

“Crime Writing Does Not Pay, Say Authors”. Daily Telegraph, 21 $1^{\text {st }}$ May 1973.

Darlington, Joseph. "Cell of One: B.S. Johnson, Christie Malry, and the Angry Brigade”. B.S. Johnson and the Post-War Avant Garde. Julia Jordan and Martin Ryle, eds. London: Picador, 2014. 
Duffy, Maureen. Letter to Brigid Brophy and Victoria Bonham-Carter, n.d. [1973a]. Held in King's College Archive.

Duffy, Maureen. Letter to Giles Gordon, $8^{\text {th }}$ August 1973. Held in King's College Archive.

Duffy, Maureen. Letter to Nicholas Wollaston, $3^{\text {rd }}$ July 1973. Held in King's College Archive.

Duffy, Maureen. Letter to O.S. Thompson, $2^{\text {nd }}$ October 1973. Held in King's College Archive.

Duffy, Maureen. List of WAG Publications in National Press, December 1972. Held in King's College Archive.

Duffy, Maureen. Notes, unlabelled, 1972. Held in King's College Archive.

Duffy, Maureen. Private minutes, n.d. [1973b]. Held in King's College Archive.

Duffy, Maureen. Template Letter, $10^{\text {th }}$ May 1974. Held in King's College Archive.

Duffy, Maureen. WAG Membership List, $14^{\text {th }}$ July 1972. Held in King's College Archive.

Dulch, J. Memo to Brigid Brophy, $16^{\text {th }}$ February 1974. Held in King's College Archive.

East Anglian Division of WAG Membership List, $16^{\text {th }}$ October 1973. Held in King's College Archive.

“Editorial". Southern Arts, No. 7, 1974.

Figes, Eva. "B.S. Johnson.” The Review of Contemporary Fiction, Vol. 5, No. 2, 1985.

Fountain, Nigel. Underground. London: Routledge, 1988.

Gordon, Giles. Letter to Lord Goodman, $29^{\text {th }}$ October 1973. Held in King's College Archive.

Gordon, Giles. Letter to Maureen Duffy, n.d. [1973]. Held in King's College Archive.

Gordon, Giles. Letter to Maureen Duffy, Brigid Brophy and B.S. Johnson, $6^{\text {th }}$ August 1973. Held in King's College Archive.

Harding, William, Giles Gordon, B.S. Johnson, Maureen Duffy and Brigid Brophy. Letter to the Editor of The Times, $30^{\text {th }}$ March 1973. Held in King's College Archive.

Heppenstall, Rayner. The Master Eccentric. John Goodman, ed. London: Allison and Busby, 1986.

Holroyd, Michael. Letter to B.S. Johnson, $16^{\text {th }}$ October 1973. Held in King's College Archive.

Hughes, Ted. Letter to Maureen Duffy and Brigid Brophy, n.d. [1974]. Held in King's College Archive.

Johnson, B.S. Aren't You Rather Young to be Writing Your Memoirs? London: Hutchinson, 1973.

Johnson, B.S. Notebook 8, started $1^{\text {st }}$ May 1969. Held in British Library.

Larsson, Bengt, Martin Letell and Håkan Thörn. "Social Engineering, Governance and Governmentality”. Transformations of the Swedish Welfare State. Larsson, Thörn and Letell, eds. London: Palgrave Macmillan, 2012.

“Lending Rights and Wrongs". The Guardian, 21 ${ }^{\text {st }}$ November 1972.

“Letters". The Times, 20 $0^{\text {th }}$ November 1973.

Lindsay, Jack. "Letter". The Times, $18^{\text {th }}$ August 1973.

Lissauer, Frank. Letter to Maureen Duffy, $25^{\text {th }}$ February 1974. Held in King's College Archive.

Minutes of a Books Committee Meeting Held at the Guild Office on $17^{\text {th }}$ November 1974. Held in King's College Archive. 
“PLR: Serving Authors Since 1979”. British Library. Website: https://www.bl.uk/plr

"Public Lending Right". The Society of Authors. Website: https://www2.societyofauthors.org/ where-we-stand/public-lending-right-plr/

“Public Lending Right”. The Times, $9^{\text {th }}$ November 1973.

"Public Lending Right: How it Applies". Gov.uk. Website: https://www.gov.uk/guidance/publiclending-right-how-it-applies

Ross, Nancy L. "Proposed: Residuals for Authors”. Washington Post, $11^{\text {th }}$ October 1973.

Seddon, Melanie. “B.S. Johnson and Maureen Duffy. A Conversation.” BSJ: The B.S. Johnson Journal, Issue 1, 2014.

Thane, Pat. "Towards Equal Opportunities? Women in Britain since 1945”. Britain Since 1945. Terry Gourvish and Alan O’Day, eds. London: Macmillan, 1991.

The Society of Authors, 2019.

Wise, Nan. Letter to Maureen Duffy, $6^{\text {th }}$ May 1973. Held in King's College Archive.

Wollaston, Nicholas. Letter to the Society of Authors, $4^{\text {th }}$ July 1973. Held in King's College Archive.

Yorke, Margaret. Letter to Maureen Duffy, $30^{\text {th }}$ October 1973. Held in King's College Archive.

\section{ABSTRACTS}

In 1972, the experimental writers Brigid Brophy and Maureen Duffy came together with three friends to found the Writer's Action Group (WAG). The group aimed to improve the financial lot of British writers, being inspired by an article in the Bookseller stating that the average author earned less in 1971 than they had done in 1966 even before taking into account the rapid inflation of the new decade. Within a year, they had published 17 articles arguing for writers to unionise and fight for Public Lending Right (PLR), a small royalty fee to be paid every time a writer's book was borrowed from a public library. Other writers flocked to join WAG including B.S. Johnson, Giles Gordon, Eva Figes, Ted Hughes, Anthony Burgess, Doris Lessing and Raymond Williams. The fight for Public Lending Right was won in 1974 when the Public Lending Right Act was voted through the Commons. It is a story of high passions, entrenched beliefs and internecine conflicts. In particular, the group's struggle with the Society of Authors involved a dramatic escalation from initial cordiality, through each side trashing the other in the press, to a final, dramatic showdown during the Society's 1973 AGM. The conflict represented a core contention at the heart of post-war British writing: are writers to be seen as workers or as aesthetes? Using materials sourced from a wide range of archives alongside interviews with participants, this paper charts the rise of WAG from a personal passion project through to a radical movement and finally into a mature campaigning body.

En 1972, les écrivains expérimentaux Brigid Brophy et Maureen Duffy se réunirent avec trois amis pour fonder le Writer's Action Group (WAG). Le groupe visait à améliorer le sort financier des écrivains britanniques, inspiré par un article de Bookseller qui affirmait que l'auteur moyen gagnait moins en 1971 qu'en 1966, même sans tenir compte de l'inflation rapide de la nouvelle décennie. En l'espace d'un an, le groupe publica 17 articles prônant la syndicalisation des écrivains et la lutte pour le Droit de prêt public (DPP), une petite redevance payée chaque fois que le livre d'un écrivain est emprunté dans une bibliothèque publique. D'autres écrivains sont venus rejoindre le WAG, notamment B.S. Johnson, Giles Gordon, Eva Figes, Ted Hughes, Anthony Burgess, Doris Lessing et Raymond Williams. La lutte pour le droit de prêt public fut gagnée en 
1974 lorsqu'une loi sur le droit de prêt public fut adoptée par la Chambre des Communes. Cet article fait le récit des passions fortes, des croyances bien ancrées et des conflits internes qui aboutirent à cette loi. Un moment clé fut la lutte du groupe avec la Society of Authors qui connut une escalade dramatique, de la convivialité initiale à l'épreuve de force finale et dramatique lors de l'assemblée générale annuelle de la Society of Authors en 1973, en passant par le dénigrement des uns et des autres dans la presse. Le conflit représentait une controverse au cœur de l'écriture britannique d'après-guerre : les écrivains doivent-ils être considérés comme des travailleurs ou des esthètes ? À l'aide de documents provenant d'un large éventail d'archives et d'entretiens avec les participants dans cette lutte, cet article retrace l'ascension de WAG depuis ses prémisses comme projet personnel, puis par sa transformation en un mouvement radical jusqu'à aboutir à un instrument de campagne efficace.

\section{INDEX}

Mots-clés: droit de prêt public, littérature d'après-guerre, littérature anglophone, syndicat d'auteurs, Brophy Brigid, Duffy Maureen, Hughes Ted, Society of Authors, Writer's Action Group, législation, bibliothèques publiques

Keywords: public lending right, post-war literature, English literature, writer's unions, Brophy Brigid, Duffy Maureen, Hughes Ted, Society of Authors, Writer's Action Group, legislation, public libraries

\section{AUTHOR}

\section{JOSEPH DARLINGTON}

Joseph Darlington is Programme Leader for BA(Hons) Digital Animation with Illustration at Futureworks Media School. He is the author of The Experimentalists (forthcoming from Bloomsbury, 2022), Christine Brooke-Rose and Post-War Literature (Palgrave, 2021), and British Terrorist Novels of the 1970s (Palgrave, 2018). He is co-editor of the Manchester Review of Books and formerly editor of BSJ: The B.S. Johnson Journal. Contact: joe.darlington AT futureworks.ac.uk 